\title{
Streptomyces pharmamarensis sp. nov. isolated from a marine sediment
}

\author{
Lorena Carro, ${ }^{1}$ Paz Zúñiga, ${ }^{2}$ Fernando de la Calle ${ }^{2}$ and Martha E. Trujillo ${ }^{1}$ \\ ${ }^{1}$ Departamento de Microbiología y Genética, Edificio Departamental, Lab. 205, \\ Campus Miguel de Unamuno, Universidad de Salamanca, Salamanca, Spain \\ ${ }^{2}$ PharmaMar, Avenida de los Reyes 1, 28770 Colmenar, Madrid, Spain
}

Correspondence

Martha E. Trujillo

mett@usal.es
The genus Streptomyces (Waksman \& Henrici, 1943) encompasses aerobic, highly branched filamentous actinomycetes with LL-diaminopimelic acid in their cell walls. Strains of the genus Streptomyces attract much interest due to their importance in biotechnological processes and their ability to produce many useful compounds. Although at the time of writing there are more than 500 validly published names (Euzéby, 2011; http://www.bacterio.cict. $\mathrm{fr} / \mathrm{s} /$ streptomycesa.html), the genus is still considered a rich microbial source for new natural compounds and isolation of novel strains is still part of screening programs in pharmaceutical companies. Furthermore, the diversity of marine streptomycetes is still poorly studied and the marine environment is considered a relatively untapped niche.

Strain PM267 ${ }^{\mathrm{T}}$ was isolated from a marine sediment sample collected at a depth of $43 \mathrm{~m}$ in the Mediterranean Sea (Italy). The micro-organism was isolated from a suspension of the sediment sample spread on nutrient agar plates of the following composition $\left(\mathrm{g} \mathrm{l}^{-1}\right)$ : Lasparagine, 2.5; glycerol, 20; $\mathrm{NaCl}, \quad 5.34 ; \mathrm{KCl}, 0.15$;

The GenBank/EMBL/DDBJ accession number for the 16S rRNA gene sequence of strain PM267 is FR693804.

A supplementary table and five figures are available with the online version of this paper.
$\mathrm{MgSO}_{4} \cdot 7 \mathrm{H}_{2} \mathrm{O}, 0.1 ; \quad \mathrm{FeSO}_{4} \cdot 7 \mathrm{H}_{2} \mathrm{O}, 0.12 ; \mathrm{Na}_{2} \mathrm{SO}_{4}, 7.5$; $\mathrm{MgCl}_{2} .6 \mathrm{H}_{2} \mathrm{O}, 2.4 ; \mathrm{CaCO}_{3}, 0.1$; agar, 20; supplemented with cycloheximide $(0.71 \mathrm{mM})$ and nalidixic acid $(0.79$ $\mathrm{mM}$ ). The plates were incubated at $28{ }^{\circ} \mathrm{C}$ for one month under atmospheric pressure. After this period, colonies were picked and transferred onto agar plates of ATCC Medium 172 (ATCC, 1984). The purified strain was stored as a glycerol suspension $(20 \% \mathrm{v} / \mathrm{v})$ at $-80{ }^{\circ} \mathrm{C}$ for longterm maintenance. Morphological features of isolate PM $267^{\mathrm{T}}$ were observed by light microscopy (Leica; CTR MIC) using 5- and 7-day-old cultures grown on ISP 2 (International Streptomyces Project medium 2; Shirling \& Gottlieb, 1966) agar supplemented with $2 \%(\mathrm{w} / \mathrm{v}) \mathrm{NaCl}$ at $28{ }^{\circ} \mathrm{C}$. Spore arrangement and ornamentation were observed by scanning electron microscopy (DSM 940; Zeiss) using 4-week-old cultures grown on the same medium at $28{ }^{\circ} \mathrm{C}$. The Gram-stain reaction (Doetsch, 1981) was performed on a 4-day-old culture.

Strain PM $267^{\mathrm{T}}$ produced extensively branched substrate and aerial hyphae that carried spiral spore chains (Spirales) with multiple turns containing more than 10 spores (Fig. S1, available in IJSEM Online). Spores $(1.0-1.2 \mu \mathrm{m})$ were oval, non-motile and had a smooth spore-surface. Strain PM $267^{\mathrm{T}}$ was Gram-stain-positive.

The $16 \mathrm{~S}$ rRNA gene of strain PM267 ${ }^{\mathrm{T}}$ was amplified and directly sequenced using the REDExtract-N-Amp Plant 


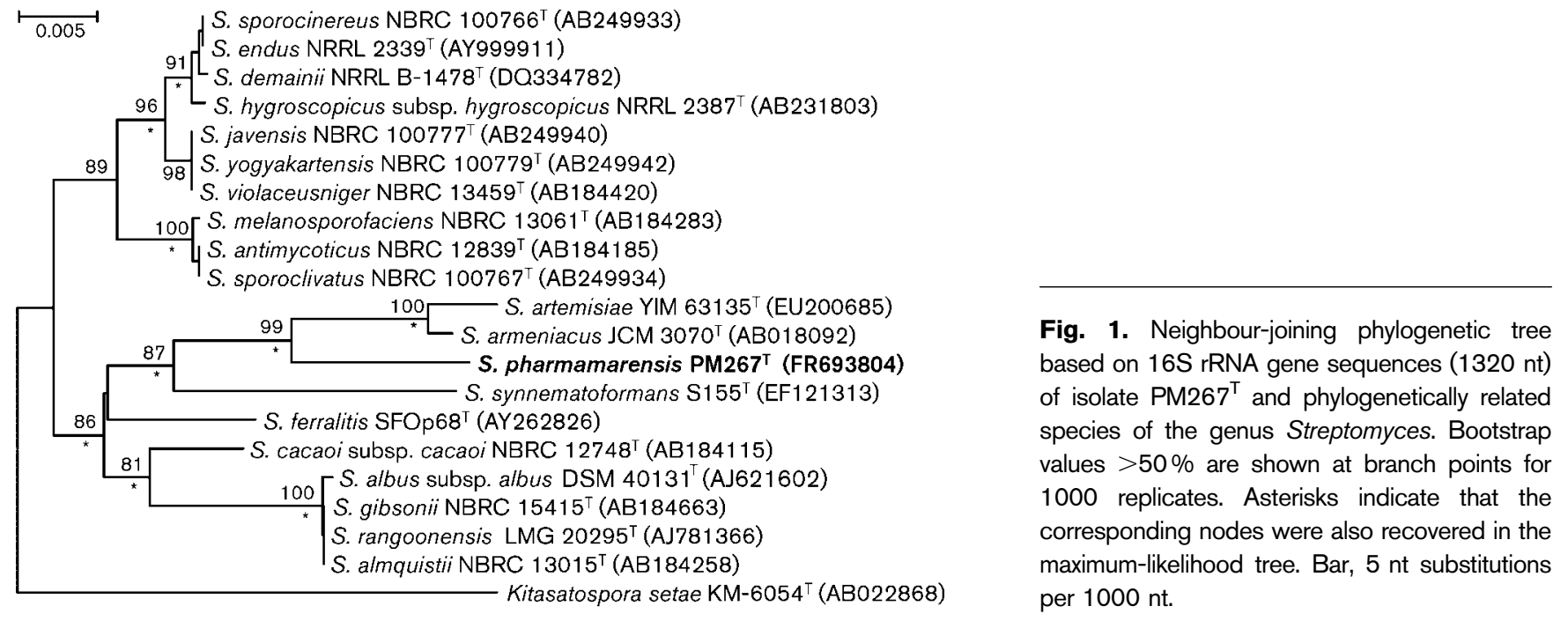

PCR kit (Sigma) and procedures described previously (Rivas et al., 2003; Trujillo et al., 2007). The contig obtained was compared with those sequences deposited in the public databases and the EzTaxon server (Chun et al., 2007), which was also used to calculate pairwise sequence similarities. The sequences of strain PM267 ${ }^{\mathrm{T}}$ and the most closely related taxa were retrieved from GenBank and aligned using the CLUSTAL x program (Thompson et al., 1997). Phylogenetic distances were calculated with Kimura's two-parameter model (Kimura, 1980) and evolutionary trees were inferred using the maximumparsimony (Fitch, 1971), neighbour-joining (Saitou \& Nei, 1987) and maximum-likelihood methods (Felsenstein, 1981). Phylogenetic analyses were performed using the software packages MEGA4 (Tamura et al., 2007) and ARB (Ludwig et al., 2004). Branch support based on 1000 replications was calculated to evaluate the tree topologies.

The $1458 \mathrm{bp}$ sequence corresponding to the 16S rRNA gene of strain $\mathrm{PM} 267^{\mathrm{T}}$ was compared with sequences deposited in the public databases. The highest levels of sequence similarity were found with sequences related to the genus Streptomyces, namely Streptomyces artemisiae YIM $63135^{\mathrm{T}}(97.1 \%)$, Streptomyces armeniacus DSM $43125^{\mathrm{T}}(97.1 \%)$, Streptomyces ferralitis DSM $41836^{\mathrm{T}}$ $(96.9 \%)$ and Streptomyces cacaoi subsp. cacaoi DSM $40057^{\mathrm{T}}(96.8 \%)$. Sequence similarities with other strains of the genus Streptomyces were lower than $96.6 \%$. The results of phylogenetic analyses using the maximumlikelihood and maximum-parsimony tree-making algorithms were very similar (Figs S2 and S3). Fig. 1 shows the relationship between strain $\mathrm{PM} 267^{\mathrm{T}}$ and its closest phylogenetic neighbours. The new isolate formed a cluster with S. artemisiae YIM $63135^{\mathrm{T}}$, S. armeniacus JCM $3070^{\mathrm{T}}$ and Streptomyces synnematoformans $\mathrm{S}_{155^{\mathrm{T}}}$. Branches within the cluster were supported by high bootstrap values between 87 and $100 \%$. These results confirmed the close relationship of strain $\mathrm{PM} 267^{\mathrm{T}}$ to the genus Streptomyces.
Lanoot et al. (2004, 2005) reported a good correlation between BOX-PCR profiling and DNA-DNA hybridization in the genus Streptomyces, whereby strains showing more than $70 \%$ DNA-DNA hybridization values shared almost identical BOX fingerprints. Therefore, this technique was applied to obtain BOX profiles for strain $\mathrm{PM} 267^{\mathrm{T}}$ and five type strains following the procedure of Trujillo et al. (2010) to guarantee differentiation at the genomic level.

A dendrogram based on the Pearson moment coefficient and unweighted-pair group method average (UPGMA) clustering method was reconstructed with the BOX-PCR profiles obtained for the strains studied (Fig. S4). Isolate $\mathrm{PM} 267^{\mathrm{T}}$ was clearly differentiated from the type strains of S. artemisiae, S. armeniacus, S. cacaoi subsp. cacaoi, $S$. ferralitis and S. synnematoformans. The $\mathrm{G}+\mathrm{C}$ content of the DNA determined by the thermal melting point method (Mandel \& Marmur, 1968) was $71.2 \mathrm{~mol} \%$.

Cultural characteristics of isolate $\mathrm{PM} 267^{\mathrm{T}}$ and $S$. armeniacus DSM $43125^{\mathrm{T}}$, S. artemisiae DSM $41953^{\mathrm{T}}$, S. cacaoi subsp. cacaoi DSM $40057^{\mathrm{T}}$, S. ferralitis DSM $41836^{\mathrm{T}}$ and S. synnematoformans DSM $41902^{\mathrm{T}}$ were determined on Bennett's (Jones, 1949), oatmeal (ISP 3; Shirling \& Gottlieb, 1966), SA1 (Trujillo et al., 2005), yeast-extract malt-extract (ISP 2) and yeast-mannitol (YMA; Vincent, 1970) agars. Media for strain PM $267^{\mathrm{T}}$ were supplemented with $2 \%(\mathrm{w} / \mathrm{v}) \mathrm{NaCl}$.

Strain PM267 $7^{\mathrm{T}}$ showed abundant growth on SA1 agar, but moderate growth on Bennett's, ISP 2 and ISP 3 and poor growth on YMA. Substrate mycelium colour was creamwhite on these media except SA1, on which it was light brown; white aerial mycelium was scantly produced on ISP 2 agar while diffusible pigments were not detected. Differences in cultural characteristics of related type strains are given in Table S1.

Chemotaxonomic analyses were carried out to support the phylogenetic affiliation of strain $\mathrm{PM} 267^{\mathrm{T}}$ to the genus 
Table 1. Cellular fatty acid profiles of strain $\mathrm{PM} 267^{\top}$ and Streptomyces artemisiae DSM $41953^{\top}$

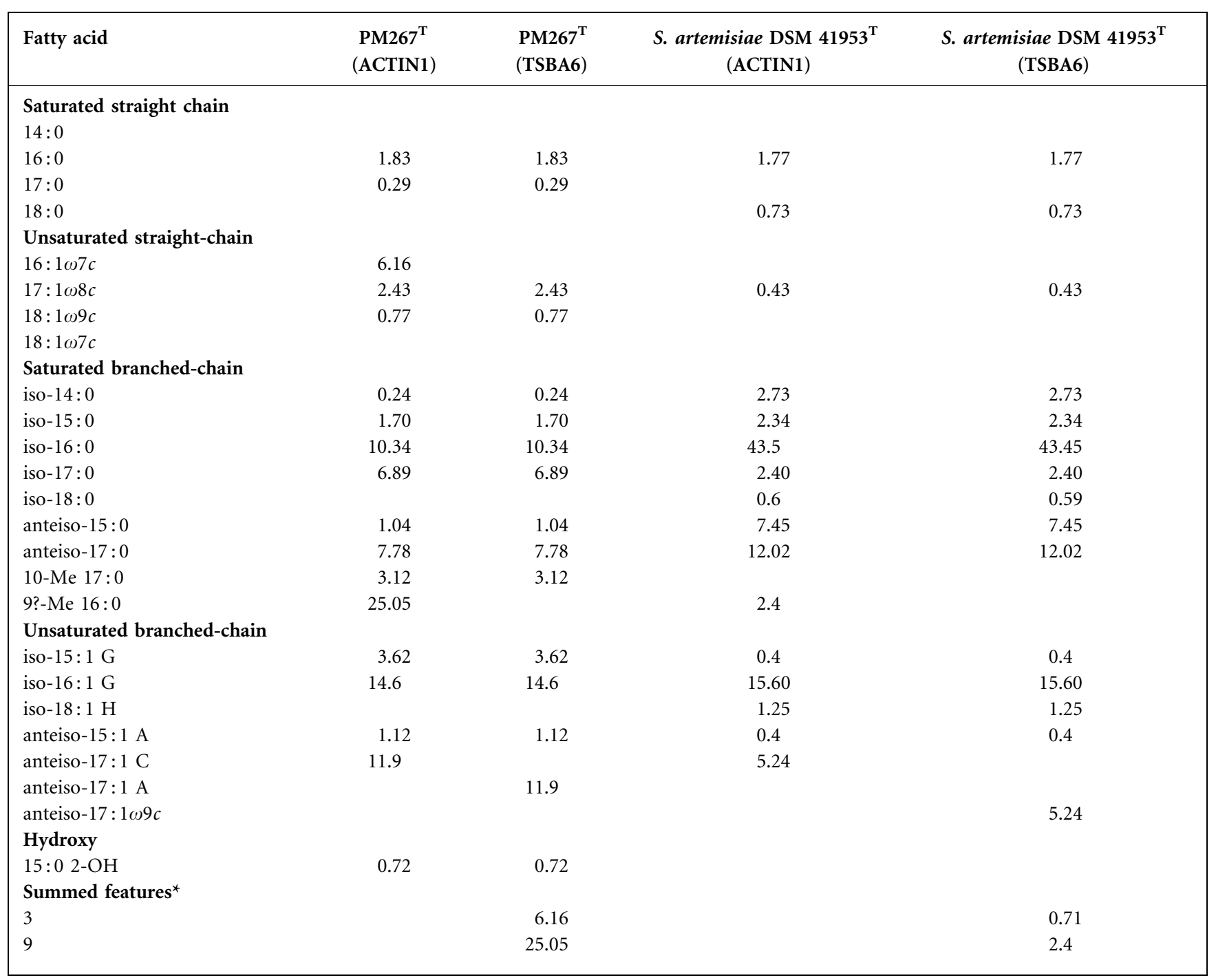

*Summed feature 3 contains $16: 1 \omega 7 c / 16: 1 \omega 6 c$; summed feature 9 contains iso-17:1 $1 \omega 9 c / 10-\mathrm{Me} 16: 0$.

Streptomyces. The strain was grown in ISP 2 broth (supplemented with $2 \% \mathrm{w} / \mathrm{v} \mathrm{NaCl}$ ) in flasks on a rotary shaker at 120 r.p.m. and $28{ }^{\circ} \mathrm{C}$ for 1 week. Biomass was harvested, washed in distilled water and freeze-dried. Isomers of diaminopimelic acid in whole-cell hydrolysates were determined by TLC on cellulose plates using the solvent system of Rhuland et al. (1955). Polar lipids and menaquinones were prepared according to the method of Minnikin et al. (1984) and analysed by two-dimensional TLC and HPLC, respectively. Methyl esters of cellular fatty acids were prepared from cells grown for 7 days until good growth was obtained on TSBA (trypticase soy broth agar; Becton Dickinson) plates supplemented with $2 \%(\mathrm{w} / \mathrm{v})$ $\mathrm{NaCl}$ and analysed using the standard MIDI system, Sherlock version 6.1 (Microbial ID). TSBA6 and ACTIN1 databases were used for peak identification. S. artemisiae
DSM $41953^{\mathrm{T}}$ was included for comparison, but this strain was grown for 5 days on TSBA without $\mathrm{NaCl}$.

LL-Diaminopimelic acid was detected in the peptidoglycan of strain PM267 ${ }^{\mathrm{T}}$, which is characteristic for members of the genus Streptomyces. The major menaquinone found was MK-9 $\left(\mathrm{H}_{8}\right)(74 \%)$, followed by MK-9 $\left(\mathrm{H}_{6}\right)(9 \%)$, MK$9\left(\mathrm{H}_{2}\right)(6 \%), \mathrm{MK}-10\left(\mathrm{H}_{2}\right)(3 \%), \mathrm{MK}-9\left(\mathrm{H}_{4}\right)(0.5 \%)$ and MK-10 (0.5\%). This pattern differs from that of its closest phylogenetic neighbour, S. artemisiae YIM $63135^{\mathrm{T}}$, where MK-9 $\left(\mathrm{H}_{6}\right)(62.8 \%)$, MK-9 $\left(\mathrm{H}_{8}\right)(31.4 \%)$ and MK-9 $\left(\mathrm{H}_{4}\right)$ (5.9\%) were reported (Zhao et al., 2010), while MK-9 $\left(\mathrm{H}_{8}\right)$ was found in S. ferralitis (Saintpierre-Bonaccio et al., 2004). Unfortunately, menaquinone data are not available for $S$. armeniacus or $S$. cacaoi. The presence of $\mathrm{MK}-9\left(\mathrm{H}_{8}\right)$ and MK-9 $\left(\mathrm{H}_{6}\right)$ is characteristic of strains belonging to the genus 
Table 2. Differential characteristics between strain $P M 267^{\top}$ and related species of the genus Streptomyces

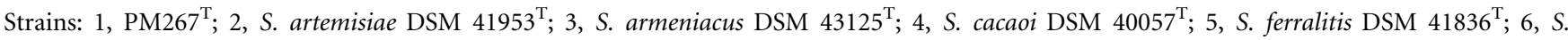
synnematoformans DSM $41902^{\mathrm{T}}$. All data obtained from the present study except where indicated. + , Positive; -, negative; w, weakly positive; ND, not determined.

\begin{tabular}{|c|c|c|c|c|c|c|}
\hline Characteristic & 1 & 2 & 3 & 4 & 5 & 6 \\
\hline \multicolumn{7}{|l|}{ Growth with $\mathrm{NaCl}(\mathrm{w} / \mathrm{v})$} \\
\hline $5 \%$ & + & + & + & + & + & - \\
\hline $7 \%$ & + & - & + & - & - & - \\
\hline $9 \%$ & + & - & - & - & - & - \\
\hline Nitrate reduction & - & - & - & - & - & + \\
\hline \multicolumn{7}{|l|}{ Degradation of: } \\
\hline Gelatin & + & + & + & + & - & - \\
\hline Starch & + & + & + & + & - & + \\
\hline Tween 20 & + & + & + & + & - & + \\
\hline L-Tyrosine & - & - & - & - & + & - \\
\hline Urea & - & - & + & + & + & - \\
\hline Xylan & + & - & - & + & + & - \\
\hline \multicolumn{7}{|l|}{ Growth at: } \\
\hline $12^{\circ} \mathrm{C}$ & - & + & - & + & - & - \\
\hline $20{ }^{\circ} \mathrm{C}$ & + & + & + & + & + & - \\
\hline $37^{\circ} \mathrm{C}$ & - & + & - & + & + & - \\
\hline $\mathrm{pH} 4.5$ & - & - & - & - & + & - \\
\hline $\mathrm{pH} 5.5$ & - & - & - & + & + & - \\
\hline $\mathrm{pH} 9.0$ & - & - & - & + & - & - \\
\hline \multicolumn{7}{|l|}{ Carbon sources $(1 \%, \mathrm{w} / \mathrm{v})$} \\
\hline Cellobiose & + & + & - & + & + & - \\
\hline Galactose & + & + & - & + & + & - \\
\hline Glucose & + & + & - & + & + & - \\
\hline L-Arabinose & + & - & $\mathrm{w}$ & + & + & + \\
\hline Maltose & + & - & - & $\mathrm{W}$ & + & - \\
\hline Mannitol & + & - & $\mathrm{w}$ & + & + & + \\
\hline Raffinose & + & - & - & + & + & + \\
\hline Rhamnose & + & + & + & + & - & - \\
\hline Sucrose & + & - & - & - & - & + \\
\hline Trehalose & + & + & - & $\mathrm{W}$ & + & - \\
\hline L-Asparagine & - & + & - & + & - & - \\
\hline L-Lysine & + & + & - & + & + & + \\
\hline L-Proline & + & + & - & + & + & - \\
\hline L-Tyrosine & + & - & - & - & + & - \\
\hline \multicolumn{7}{|l|}{ Enzymic activity } \\
\hline Acid phosphatase & + & + & - & + & + & - \\
\hline$N$-Acetyl- $\beta$-glucosaminidase & + & + & - & + & + & + \\
\hline Pyrazinamidase & - & - & + & - & - & - \\
\hline Pyrrolidonyl arylamidase & + & - & - & - & - & - \\
\hline Trypsin & + & + & - & - & - & - \\
\hline$\alpha$-Chymotrypsin & + & - & - & - & + & - \\
\hline$\alpha$-Fucosidase & + & - & - & - & - & - \\
\hline$\alpha$-Glucosidase & - & - & - & + & + & - \\
\hline$\alpha$-Mannosidase & + & - & - & - & + & - \\
\hline$\beta$-Galactosidase & + & - & - & + & + & - \\
\hline$\beta$-Glucuronidase & - & - & - & - & - & + \\
\hline Menaquinone composition ${ }^{*}$ & $\begin{array}{l}\text { MK-9 }\left(\mathrm{H}_{2}\right), \text { MK- } 9\left(\mathrm{H}_{4}\right), \text { MK- } 9\left(\mathrm{H}_{6}\right) \\
\text { MK- } 9\left(\mathrm{H}_{8}\right), \text { MK-10, MK-10 }\left(\mathrm{H}_{2}\right)\end{array}$ & $\begin{array}{l}\text { MK-9 }\left(\mathrm{H}_{4}\right), \text { MK- } \\
9\left(\mathrm{H}_{6}\right), \mathrm{MK}-9\left(\mathrm{H}_{8}\right)\end{array}$ & $\begin{array}{l}\text { MK-9 }\left(\mathrm{H}_{4}\right) \\
\text { MK-9 }\left(\mathrm{H}_{6}\right)\end{array}$ & ND & MK-9 $\left(\mathrm{H}_{8}\right)$ & $\begin{array}{l}\text { MK-9 }\left(\mathrm{H}_{4}\right), \text { MK- } \\
\left.9\left(\mathrm{H}_{6}\right), \text { MK-9( } \mathrm{H}_{8}\right)\end{array}$ \\
\hline
\end{tabular}

*Data for taxa 2-6 from Zhao et al. (2010); Wellington \& Williams (1981); Saintpierre-Bonaccio et al. (2004); Hozzein \& Goodfellow (2007). 
Streptomyces and supports the assignment of strain PM $267^{\mathrm{T}}$ to the genus Streptomyces. The phospholipid composition of the novel strain included diphosphatidylglycerol, phosphatidylglycerol, phosphatidylethanolamine, phosphatidylinositol, phosphatidylinositol mannoside and an unidentified phospholipid. The phospholipid type, PII (Kroppenstedt, 1985), agrees with that reported for the genus Streptomyces. TLC plates with the phospholipid profile of strain $\mathrm{PM} 267^{\mathrm{T}}$ developed with molybdenum blue, ninhydrin and anisaldehyde reagents are shown in Fig. S5.

The major fatty acids detected in isolate $\mathrm{PM} 267^{\mathrm{T}}$ were a mixture of unsaturated straight-chain and saturated/ unsaturated branched-chain fatty acids. According to the database TSBA6, the major component was summed feature $9(25.05 \%)$ which contained iso-17: $1 \omega 9 c$ and/or 10-Me 16:0 followed by iso-16:1 (14.6\%), anteiso-17:1 $(11.9 \%)$, iso-16:0 (10.34\%), anteiso-17:0 (7.8\%) and iso-17:0 $(6.9 \%)$. When the data were compared against the database ACTIN1 the same fatty acids were identified except for summed feature 9, which was identified as 9?Me 16:0. Therefore, this mixture could not be resolved by the MIDI system. In the case of S. artemisiae DSM $41953^{\mathrm{T}}$, a similar profile was detected using both databases and the major fatty acids found were iso-16:0 (43.5\%), iso-16:1 (15.6\%), anteiso-17:0 (12.0\%) and anteiso-15:0 (7.5\%); however, summed feature 9 only accounted for $2.4 \%$ of the components. These fatty acids were also reported by Zhao et al. (2010) as major components. A detailed profile of both strains is given in Table 1.

Catalase and oxidase activities were determined as described previously (Trujillo et al., 2006). Hydrolysis of various chemical compounds was determined according to Trujillo et al. (2005). Carbon source utilization was performed as described by Williams et al. (1983). Determination of temperature and $\mathrm{pH}$ for growth and tolerance to $\mathrm{NaCl}$ was carried out on SAl agar. API ZYM tests (bioMérieux) were also carried out following the manufacturer's instructions. The type strains $S$. artemisiae DSM $41953^{\mathrm{T}}$, S. armeniacus DSM $43125^{\mathrm{T}}$, S. cacaoi subsp. cacaoi DSM $40057^{\mathrm{T}}$, S. ferralitis DSM $41836^{\mathrm{T}}$ and $S$. synnematoformans DSM $41902^{\mathrm{T}}$ were included for comparison in all tests. Where appropriate, media were supplemented with $2 \%(\mathrm{w} / \mathrm{v}) \mathrm{NaCl}$.

Strain PM $267^{\mathrm{T}}$ differed from the five type strains of the genus Streptomyces compared by its high tolerance to $\mathrm{NaCl}$ (up to $9 \%, w / v$ ), inability to reduce nitrate compared to $S$. synnematoformans DSM $41902^{\mathrm{T}}$, and its ability to degrade different chemical compounds such as xylan. L-Arabinose, maltose, mannitol, raffinose and sucrose were used as carbon sources by strain $\mathrm{PM} 267^{\mathrm{T}}$, but not by S. artemisiae DSM $41953^{\mathrm{T}}$. Several enzymic substrates were also useful for differentiating strain $\mathrm{PM} 267^{\mathrm{T}}$ from its closest phylogenetic relatives. These and the results of other tests are provided in Table 2.

Given the differences found at the genotypic and phenotypic level, strain PM $267^{\mathrm{T}}$ should be classified as a novel species in the genus Streptomyces, for which the name proposed is Streptomyces pharmamarensis sp. nov.

\section{Description of Streptomyces pharmamarensis sp. nov.}

Streptomyces pharmamarensis sp. nov. (phar.ma.ma.ren'sis. N.L. masc. adj. pharmamarensis pertaining to PharmaMar, the company where the strain was isolated).

Gram-stain-positive halotolerant aerobic actinomycete that forms extensively branched substrate and aerial hyphae that carry spiral spore chains (Spirales) with multiple turns containing more than 10 spores. Spores $(1.0-1.2 \mu \mathrm{m})$ are oval, non-motile and have smooth surfaces. Substrate mycelium colour is cream-white on several media except $\mathrm{SA} 1$, on which it is light brown; white aerial mycelium is scantly produced on ISP 2 agar. Diffusible pigments have not been observed. Cell wall contains LL-diaminopimelic acid. Menaquinones found are MK-9 $\left(\mathrm{H}_{8}\right)$, MK- $9\left(\mathrm{H}_{6}\right)$, MK-9 $\left(\mathrm{H}_{2}\right)$, MK-10 $\left(\mathrm{H}_{2}\right)$, MK-9 $\left(\mathrm{H}_{4}\right)$ and MK-10. The phospholipid composition includes diphosphatidylglycerol, phosphatidylglycerol, phosphatidylethanolamine, phosphatidylinositol, phosphatidylinositol mannosides (2) and one unidentified phospholipid. The DNA G+C content of the genomic DNA of the type strain is $71.2 \mathrm{~mol} \%$. Positive for catalase and oxidase. Grows in the presence of $9 \% \mathrm{NaCl}(\mathrm{w} / \mathrm{v})$ with an optimum of $2 \%$. Grows well between 20 and $30{ }^{\circ} \mathrm{C}$, but not at $37{ }^{\circ} \mathrm{C}$. Utilizes L-lysine, melibiose, raffinose, starch, sucrose, L-serine, Ltyrosine, L-valine and xylose as carbon sources, but not Lasparagine, cellulose, citrate, gluconic acid, quinic acid or sorbose. Positive for alkaline phosphatase, esterase (C4), esterase lipase (C8), leucine arylamidase, valine arylamidase, cystine arylamidase, naphthol-AS-BI-phosphohydrolase and $\mathrm{N}$-acetylglucosaminidase; negative for lipase (C14), $\alpha$-galactosidase and $\beta$-glucosidase. Additional data are given in Table 2.

The type strain PM267 ${ }^{\mathrm{T}}\left(=\right.$ CECT $\left.7841^{\mathrm{T}}=\mathrm{DSM} 42032^{\mathrm{T}}\right)$ was isolated from a marine sediment sample collected at a depth of $43 \mathrm{~m}$ in the Mediterranean Sea off the coast of Italy.

\section{Acknowledgements}

This work was funded by PharmaMar under the project contract Art.83 L.O.U. between the Universidad de Salamanca and PharmaMar. We thank Professor J. P. Euzéby for his advice in naming the new species.

\section{References}

ATCC (1984). Media Handbook. Rockville, MD: American Type Culture Collection.

Chun, J., Lee, J.-H., Jung, Y., Kim, M., Kim, S., Kim, B. K. \& Lim, Y. W. (2007). EzTaxon: a web-based tool for the identification of prokaryotes based on 16S ribosomal RNA gene sequences. Int J Syst Evol Microbiol 57, 2259-2261. 
Doetsch, R. N. (1981). Determinative methods of light microscopy. In Manual of Methods for General Bacteriology, pp. 21-33. Edited by P. Gerdhardt, R. G. E. Murray, R. N. Costilow, E. W. Nester, W. A. Wood, N. R. Krieg \& G. B. Phillips. Washington: American Society for Microbiology.

Euzéby, J. (2011). List of prokaryotic names with standing in nomenclature. http://www.bacterio.cict.fr/s/streptomycesa.html.

Felsenstein, J. (1981). Evolutionary trees from DNA sequences: a maximum likelihood approach. J Mol Evol 17, 368-376.

Fitch, W. M. (1971). Toward defining the course of evolution: minimum change for a specific tree topology. Syst Zool 20, 406-416.

Hozzein, W. N. \& Goodfellow, M. (2007). Streptomyces synnematoformans sp. nov., a novel actinomycete isolated from a sand dune soil in Egypt. Int J Syst Evol Microbiol 57, 2009-2013.

Jones, K. L. (1949). Fresh isolates of actinomycetes in which the presence of sporogenous aerial mycelia is a fluctuating characteristic. J Bacteriol 57, 141-145.

Kimura, M. (1980). A simple method for estimating evolutionary rates of base substitutions through comparative studies of nucleotide sequences. J Mol Evol 16, 111-120.

Kroppenstedt, R. M. (1985). Fatty acid and menaquinone analysis of actinomycetes and related organisms. In Chemical Methods in Bacterial Systematics (Society for Applied Bacteriology Technical Series vol. 20), pp. 173-199. Edited by M. Goodfellow \& D. E. Minnikin. New York: Academic Press.

Lanoot, B., Vancanneyt, M., Dawyndt, P., Cnockaert, M. C., Zhang, J., Huang, Y., Liu, Z. \& Swings, J. (2004). BOX-PCR fingerprinting as a powerful tool to reveal synonymous names in the genus Streptomyces. Emended descriptions are proposed for the species Streptomyces cinereorectus, S. fradiae, S. tricolor, S. colombiensis, S. filamentosus, S. vinaceus and S. phaeopurpureus. Syst Appl Microbiol 27, 84-92.

Lanoot, B., Vancanneyt, M., Van Schoor, A., Liu, Z. \& Swings, J. (2005). Reclassification of Streptomyces nigrifaciens as a later synonym of Streptomyces flavovirens; Streptomyces citreofluorescens, Streptomyces chrysomallus subsp. chrysomallus and Streptomyces fluorescens as later synonyms of Streptomyces anulatus; Streptomyces chibaensis as a later synonym of Streptomyces corchorusii; Streptomyces flaviscleroticus as a later synonym of Streptomyces minutiscleroticus; and Streptomyces lipmanii, Streptomyces griseus subsp. alpha, Streptomyces griseus subsp. cretosus and Streptomyces willmorei as later synonyms of Streptomyces microflavus. Int J Syst Evol Microbiol 55, 729-731.

Ludwig, W., Strunk, O., Westram, R., Richter, L., Meier, H. Yadhukumar, Buchner, A., Lai, T., Steppi, S. \& other authors (2004). ARB: a software environment for sequence data. Nucleic Acids Res 32, 1363-1371.

Mandel, M. \& Marmur, J. (1968). Use of ultraviolet absorbance temperature profile for determining the guanine plus cytosine content of DNA. Methods Enzymol 12B, 195-206.

Minnikin, D. E., O'Donnell, A. G., Goodfellow, M., Alderson, G., Athalye, M., Schaal, K. \& Parlett, J. H. (1984). An integrated procedure for extracting bacterial isoprenoid quinones and polar lipids. J Microbiol Methods 2, 233-241.

Rhuland, L. E., Work, E., Denman, R. F. \& Hoare, D. S. (1955). The behavior of the isomers of $\alpha, \varepsilon$-diaminopimelic acid on paper chromatograms. J Am Chem Soc 77, 4844-4846.
Rivas, R., Sánchez, M., Trujillo, M. E., Zurdo-Piñeiro, J. L., Mateos, P. F., Martínez-Molina, E. \& Velázquez, E. (2003). Xylanimonas cellulosilytica gen. nov., sp. nov., a xylanolytic bacterium isolated from a decayed tree (Ulmus nigra). Int J Syst Evol Microbiol 53, 99-103.

Saintpierre-Bonaccio, D., Amir, H., Pineau, R., Lemriss, S. \& Goodfellow, M. (2004). Streptomyces ferralitis sp. nov., a novel streptomycete isolated from a New-Caledonian ultramafic soil. Int $J$ Syst Evol Microbiol 54, 2061-2065.

Saitou, N. \& Nei, M. (1987). The neighbor-joining method: a new method for reconstructing phylogenetic trees. Mol Biol Evol 4, 406425 .

Shirling, E. B. \& Gottlieb, D. (1966). Methods for characterization of Streptomyces species. Int J Syst Bacteriol 16, 313-340.

Tamura, K., Dudley, J., Nei, M. \& Kumar, S. (2007). MEGA4: molecular evolutionary genetics analysis (MEGA) software version 4.0. Mol Biol Evol 24, 1596-1599.

Thompson, J. D., Gibson, T. J., Plewniak, F., Jeanmougin, F. \& Higgins, D. G. (1997). The CLUSTAL_X windows interface: flexible strategies for multiple sequence alignment aided by quality analysis tools. Nucleic Acids Res 25, 4876-4882.

Trujillo, M. E., Fernández-Molinero, C., Velázquez, E., Kroppenstedt, R. M., Schumann, P., Mateos, P. F. \& Martínez-Molina, E. (2005). Micromonospora mirobrigensis sp. nov. Int J Syst Evol Microbiol 55, 877-880.

Trujillo, M. E., Kroppenstedt, R. M., Schumann, P. \& MartínezMolina, E. (2006). Kribbella lupini sp. nov., isolated from the roots of Lupinus angustifolius. Int J Syst Evol Microbiol 56, 407-411.

Trujillo, M. E., Kroppenstedt, R. M., Fernández-Molinero, C., Schumann, P. \& Martínez-Molina, E. (2007). Micromonospora lupini sp. nov. and Micromonospora saelicesensis sp. nov., isolated from root nodules of Lupinus angustifolius. Int J Syst Evol Microbiol 57, 2799 2804.

Trujillo, M. E., Alonso-Vega, P., Rodríguez, R., Carro, L., Cerda, M. E. \& Martínez-Molina, E. (2010). The genus Micromonospora is widespread in legume root nodules: the example of Lupinus angustifolius. ISME J 4, 1265-1281.

Vincent, J. M. (1970). The cultivation, isolation and maintenance of rhizobia. In A Manual for the Practical Study of the Root-Nodule Bacteria, pp. 1-13. Edited by J. M. Vincent. Oxford: Blackwell Scientific.

Waksman, S. A. \& Henrici, A. T. (1943). The nomenclature and classification of the actinomycetes. J Bacteriol 46, 337-341.

Wellington, E. M. H. \& Williams, S. T. (1981). Transfer of Actinoplanes armeniacus Kalakoutskii and Kusnetsov to Streptomyces: Streptomyces armeniacus (Kalakoutskii and Kusnetsov) comb. nov. Int J Syst Bacteriol 31, 77-81.

Williams, S. T., Goodfellow, M., Alderson, G., Wellington, E. M. H., Sneath, P. H. A. \& Sackin, M. J. (1983). Numerical classification of Streptomyces and related genera. J Gen Microbiol 129, 1743-1813.

Zhao, G.-Z., Li, J., Qin, S., Huang, H. Y., Zhu, W. Y., Xu, L. H. \& Li, W.-J. (2010). Streptomyces artemisiae sp. nov., isolated from surfacesterilized tissue of Artemisia annua L. Int J Syst Evol Microbiol 60, $27-32$. 